\title{
Front Matter: Volume 7000
}

, "Front Matter: Volume 7000," Proc. SPIE 7000, Optical and Digital Image Processing, 700001 (6 June 2008); doi: 10.1117/12.802443

SPIE. Event: SPIE Photonics Europe, 2008, Strasbourg, France 


\title{
PROCEEDINGS OF SPIE
}

\section{Optical and Digital Image Processing}

\author{
Peter Schelkens \\ Touradj Ebrahimi \\ Gabriel Cristóbal \\ Frédéric Truchetet \\ Editors
}

\section{7-9 April 2008}

Strasbourg, France

Sponsored by

SPIE Europe

Cosponsored by

Alsace International (France)

Conseil Général du Bas-Rhin (France)

Région Alsace (France)

Communauté Urbaine de Strasbourg (France)

Cooperating Organizations

AFOP-Association Française des Industries de l'Optique et de la Photonique (France)

EOS-European Optical Society (Germany) - EPIC-European Photonics Industry Consortium

(France) • ePIXnet (Belgium) • IOP_Institute of Physics (United Kingdom) • NEMO—Network of

Excellence on Micro-Optics (Belgium) • OLAS (Italy) • The OLLA Project (Germany) - OPERA 2015

(Belgium) • PhOREMOST (Ireland) • Photonics Knowledge Transfer Network (United Kingdom)

Photonics Cluster (United Kingdom) • Photonics4Life (Germany) • Photonics 21 (Germany)

RhenaPhotonics Alsace (France)

Published by

SPIE

Volume 7000 
The papers included in this volume were part of the technical conference cited on the cover and title page. Papers were selected and subject to review by the editors and conference program committee. Some conference presentations may not be available for publication. The papers published in these proceedings reflect the work and thoughts of the authors and are published herein as submitted. The publisher is not responsible for the validity of the information or for any outcomes resulting from reliance thereon.

Please use the following format to cite material from this book:

Author(s), "Title of Paper," in Optical and Digital Image Processing, edited by Peter Schelkens, Touradj Ebrahimi, Gabriel Cristóbal, Frédéric Truchetet, Proceedings of SPIE Vol. 7000 (SPIE, Bellingham, WA, 2008) Article CID Number.

ISSN 0277-786X

ISBN 9780819471987

Published by

SPIE

P.O. Box 10, Bellingham, Washington $98227-0010$ USA

Telephone +1 3606763290 (Pacific Time) · Fax +1 3606471445

SPIE.org

Copyright (c) 2008, Society of Photo-Optical Instrumentation Engineers

Copying of material in this book for internal or personal use, or for the internal or personal use of specific clients, beyond the fair use provisions granted by the U.S. Copyright Law is authorized by SPIE subject to payment of copying fees. The Transactional Reporting Service base fee for this volume is $\$ 18.00$ per article (or portion thereof), which should be paid directly to the Copyright Clearance Center (CCC), 222 Rosewood Drive, Danvers, MA 01923. Payment may also be made electronically through CCC Online at copyright.com. Other copying for republication, resale, advertising or promotion, or any form of systematic or multiple reproduction of any material in this book is prohibited except with permission in writing from the publisher. The CCC fee code is 0277-786X/08/\$18.00.

Printed in the United States of America.

Publication of record for individual papers is online in the SPIE Digital Library.

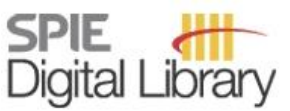

SPIEDigitalLibrary.org

Paper Numbering: Proceedings of SPIE follow an e-First publication model, with papers published first online and then in print and on CD-ROM. Papers are published as they are submitted and meet publication criteria. A unique, consistent, permanent citation identifier (CID) number is assigned to each article at the time of the first publication. Utilization of CIDs allows articles to be fully citable as soon they are published online, and connects the same identifier to all online, print, and electronic versions of the publication. SPIE uses a six-digit CID article numbering system in which:

- The first four digits correspond to the SPIE volume number.

- The last two digits indicate publication order within the volume using a Base 36 numbering system employing both numerals and letters. These two-number sets start with 00, 01, 02, 03, 04, 05, $06,07,08,09,0 \mathrm{~A}, 0 \mathrm{~B} \ldots \mathrm{OZ}$, followed by $10-1 \mathrm{Z}, 20-2 \mathrm{Z}$, etc.

The CID number appears on each page of the manuscript. The complete citation is used on the first page, and an abbreviated version on subsequent pages. Numbers in the index correspond to the last two digits of the six-digit CID number. 


\title{
Contents
}

\author{
xi Conference Committee \\ xiii Introduction
}

\section{SESSION 1 HOLOGRAPHY-INTERFEROMETRY}

700002 Superresolution microscopy using common-path phase-shifting interferometry [7000-01] V. Micó, AIDO - Technological Institute of Optics, Colour and Imaging (Spain); Z. Zalevsky, Bar-llan Univ. (Israel); J. García, Univ. de Valencia (Spain)

700003 Segmentation of macroscopic object digital holographic reconstructions using extracted depth information [7000-02]

C. P. McElhinney, B. M. Hennelly, J. B. McDonald, National Univ. of Ireland, Maynooth (Ireland); T. J. Naughton, National Univ. of Ireland, Maynooth (Ireland) and Univ. of Oulu (Finland)

$700004 \quad$ Holographic data storage using phase-only data pages [7000-03]

T. Sarkadi, P. Koppa, F. Ujhelyi, J. Reményi, G. Erdei, E. Lörincz, Budapest Univ. of Technology and Economics (Hungary)

700005 Quantitative phase restoration in differential interference contrast (DIC) microscopy [7000-04]

S. S. Kou, C. J. R. Sheppard, National Univ. of Singapore (Singapore)

\section{SESSION 2 INDUSTRIAL APPLICATIONS}

$700006 \quad$ New solutions for industrial inspection based on 3D computer tomography (Invited Paper) [7000-05]

J. Kroll, I. Effenberger, A. Verl, Fraunhofer Institut für Produktionstechnik und

Automatisierung (Germany)

700008 Automated inspection of microlens arrays [7000-07]

J. Mure-Dubois, H. Hügli, Univ. of Neuchâtel (Switzerland)

7000 0A Flaw detection and segmentation in textile inspection [7000-09]

M. S. Millán, M. Ralló, J. Escofet, Technical Univ. of Catalonia (Spain)

\section{SESSION 3 WAVELET METHODS}

7000 OB The wavelet transform on the two-sphere and related manifolds: a review (Invited Paper) [7000-10] J.-P. Antoine, Univ. Catholique de Louvain (Belgium); D. Roşca, Technical Univ. of ClujNapoca (Romania) 
7000 OD A Hilbert-space approach to the complete investigation of Vaidyanathan's procedure applied to the design of unitary filterbanks for the generation of orthogonal wavelet bases [7000-13]

P. Steffen, W. Brandhuber, Univ. of Erlangen-Nuremberg (Germany)

7000 OE Wavelet-constrained stereo matching under photometric variations [7000-14] W. Miled, École Nationale Supérieure des Télécommunications (France); J.-C. Pesquet, Univ. Paris-Est (France); M. Parent, INRIA Rocquencourt (France)

\section{SESSION 4 COMPRESSION TECHNOLOGIES}

7000 OF Sparse spike coding : applications of neuroscience to the processing of natural images (Keynote Paper) [7000-15]

L. U. Perrinet, Institut de Neurosciences Cognitives de la Méditerranée, Univ. of Provence, CNRS (France)

7000 0G Heuristic dynamic complexity coding [7000-16] J. Škorupa, J. Slowack, S. Mys, P. Lambert, R. Van de Walle, Ghent Univ. (Belgium)

$7000 \mathrm{OH} \quad$ Priority-based error protection for the scalable extension of H.264/SVC [7000-30] D. Bakker, Vrije Univ. Brussel (Belgium) and Univ. College of Antwerp (Belgium); D. Cromboom, Univ. College of Antwerp (Belgium); T. Dams, Vrije Univ. Brussel (Belgium) and Univ. College of Antwerp (Belgium); A. Munteanu, J. Barbarien, Vrije Univ. Brussel (Belgium)

7000 Ol Compression of confocal microscopy images: a comparative study [7000-18] A. A. Skodras, Imperial College of Science, Technology, and Medicine (United Kingdom); A. N. Skodras, Hellenic Open Univ. (Greece)

7000 oJ Image quality assessment through a logarithmic anisotropic measure [7000-19] S. Gabarda, G. Cristóbal, CSIC (Spain)

\section{SESSION 5 ADVANCED CAMERA SYSTEMS}

7000 OK Smart camera with embedded co-processor: a postal sorting application [7000-20] R. Mosqueron, Ecole Polytechnique Fédérale de Lausanne (Switzerland); J. Dubois, Univ. de Bourgogne (France); M. Mattavelli, Ecole Polytechnique Fédérale de Lausanne (Switzerland)

7000 OL Panoramic lens applications revisited [7000-21]

S. Thibault, ImmerVision (Canada)

7000 OM Ultra-miniature omni-directional camera for an autonomous flying micro-robot [7000-22] P. Ferrat, C. Gimkiewicz, S. Neukom, Y. Zha, A. Brenzikofer, T. Baechler, Ctr. Suisse d'Electronique et de Microtechnique SA (Switzerland)

7000 ON A CAPD based time-of-flight ranging pixel with wide dynamic range [7000-23] D. Van Nieuwenhove, W. Van der Tempel, R. Grootjans, M. Kuijk, Vrije Univ. Brussel (Belgium) 
700000 Detection of activity pattern changes among elderly with 3D camera technology [7000-24] B. Jansen, Vrije Univ. Brussel (Belgium); S. Rebel, Univ. Ziekenhuis Brussel (Belgium);

R. Deklerck, Vrije Univ. Brussel (Belgium); T. Mets, Univ. Ziekenhuis Brussel (Belgium);

P. Schelkens, Vrije Univ. Brussel (Belgium)

\section{SESSION 6 WAVELET APPLICATIONS AND DENOISING}

7000 OP Video modelling in the DWT domain [7000-25]

O. Dumitru, M. Mitrea, F. Prêteux, Institut TELECOM (France)

$7000 \mathrm{OQ} \quad$ Fringe pattern analysis using a one-dimensional modified Morlet continuous wavelet transform [7000-26]

A. Z. Abid, M. A. Gdeisat, D. R. Burton, M. J. Lalor, H. S. Abdul-Rahman, F. Lilley, Liverpool John Moores Univ. (United Kingdom)

7000 OS Discrete multiscale wavelet shrinkage and integrodifferential equations [7000-28]

S. Didas, Saarland Univ. (Germany); G. Steidl, Univ. of Mannheim (Germany); J. Weickert, Saarland Univ. (Germany)

7000 OU A wavelet transform based multiresolution edge detection and classification schema [7000-12]

G. Palacios, J. R. Beltran, Univ. de Zaragoza (Spain)

\section{SESSION 7 WATERMARKING}

7000 OV Capacity evaluation for MPEG-4 AVC watermarking (Invited Paper) [7000-31]

S. Duta, M. Mitrea, F. Prêteux, Institut TELECOM (France)

7000 OW A new watermarking method based on the use of the hyperanalytic wavelet transform [7000-33]

C. Nafornita, I. Firoiu, Politehnica Univ. Timisoara (Romania); J.-M. Boucher, GET/ENST

Bretagne, CNRS (France); A. Isar, Politehnica Univ. Timisoara (Romania)

7000 OX Image watermarking in the Hermite transform domain with resistance to geometric distortions [7000-34]

N. Baaziz, Univ. du Québec en Outaouais (Canada); B. Escalante-Ramirez,

O. Romero-Hernández, Univ. Nacional Autónoma de México (Mexico)

7000 OY A novel adaptive multi-resolution combined watermarking algorithm [7000-32]

G. Feng, Q. Lin, Hua Qiao Univ. (China)

SESSION 8 ADVANCED IMAGING

$70000 Z$ Adaptive illumination source for multispectral vision system applied to material discrimination [7000-36]

O. M. Conde, A. Cobo, P. Cantero, D. Conde, J. Mirapeix, A. M. Cubillas,

J. M. López-Higuera, Univ. de Cantabria (Spain) 
$700010 \quad$ Extended dynamic range imaging in shearography [7000-37]

R. M. Groves, G. Pedrini, W. Osten, Univ. Stuttgart (Germany)

700011 Minimum image entropy technology applied to the real-time autofocusing system of space optical remote sensors [7000-38]

L. Guo, J. Li, China Academy of Space Technology (China); Y. Li, China Univ. of Petroleum (China); S. Wang, A. Jiang, National Astronomical Observatories (China); X. Ding, Tsinghua Univ. (China); R. Peng, H. Juan, Jilin Petroleum Group Corp. (China)

700012 On a method to eliminate moving shadows in video sequences [7000-53]

B. K. Mitra, P. Birch, I. Kypraios, R. Young, C. Chatwin, Univ. of Sussex (United Kingdom)

\section{SESSION 9 MEDICAL IMAGING}

700014 Preprocessing and analysis of microarray images from integrated lensless bio-photonic sensors [7000-39]

J. Angulo, C. Lajaunie, M. Bilodeau, Ecole des Mines de Paris (France); L. Martinelli,

F. Le Boulaire, Genewave S.A.S. (France); F. Meyer, Ecole des Mines de Paris (France)

700015 Imaging of laser-induced thermo-elastic stress in biotissues with shadowgraph [7000-40]

A. I. Omelchenko, E. N. Sobol, Institute on Laser and Information Technologies (Russia)

700016 A structured light system to guide percutaneous punctures in interventional radiology [7000-41]

S. A. Nicolau, J. Brenot, L. Goffin, IRCAD (France); P. Graebling, LSIIT (France); L. Soler,

J. Marescaux, IRCAD (France)

\section{SESSION 10 INTERACTION BETWEEN OPTICS AND DIGITAL IMAGE PROCESSING}

700017 Analysis of polarization vortices generated from a polarization diffractive mask (Invited Paper) [7000-43]

I. Moreno, Univ. Miguel Hernández de Elche (Spain); C. Iemmi, Univ. Buenos Aires

(Argentina); J. Campos, M. J. Yzuel, Univ. Autónoma de Barcelona (Spain); A. Vargas, Univ. de La Frontera (Chile)

700018 The assessment of phase only filters in imaging systems by the classical optical merit functions [7000-44]

R. Hild, Univ. of Applied Sciences (Germany); J. Campos, M. Yzuel, Univ. Autónoma de Barcelona (Spain); C. Iemmi, Univ. de Buenos Aires (Argentina); R. Gimeno, J. C. Escalera, Univ. Autónoma de Barcelona (Spain)

700019 Image capture and processing for a microoptical compound-eye sensor [7000-47] R. Tudela, A. Brückner, J. Duparré, A. Bräuer, Fraunhofer Institute for Applied Optics and Precision Engineering (Germany)

7000 1B Spatial transform in non-conventional ultra-high resolution image-carrying fiber bundle [7000-46]

B. An, Shanghai Maritime Univ. (China), Shanghai Institute of Technical Physics (China) and Central Research Academy of SVA Group Co. (China); J. Gao, Shanghai Maritime Univ. (China); G. Wang, Central Research Academy of SVA Group Co. (China) 
7000 1C Scale and rotation invariant 3D object detection using spherical nonlinear correlations [7000-35]

P. García-Martínez, J. J. Vallés, C. Ferreira, Univ. de València (Spain)

$70001 \mathrm{E} \quad$ Analysis of non-ideal behavior of CAPD based time-of-flight pixels [7000-50]

R. Grootjans, W. van der Tempel, D. Van Nieuwenhove, M. Kuijk, Vrije Univ. Brussel (Belgium)

$70001 \mathrm{~F} \quad$ Applying SIMD to optical character recognition (OCR) [7000-51]

G. Yu, Vrije Univ. Brussel (Belgium) and Nomadic Embedded Systems (Belgium);

G. Lafruit, R. Stahl, Nomadic Embedded Systems (Belgium); H. Corporaal, Technical Univ. of Eindhoven (Netherlands); P. Schelkens, Vrije Univ. Brussel (Belgium)

$700016 \quad$ Image processing with JPEG2000 coders [7000-52]

P. Śliwiński, C. Smutnicki, A. Chorażyczewski, Wrocław Univ. of Technology (Poland)

$70001 \mathrm{H} \quad$ An iris recognition algorithm based on DCT and GLCM [7000-54]

G. Feng, Y. Wu, Hua Qiao Univ. (China)

$700011 \quad$ Automatic detection and recognition of traffic signs in stereo images based on features and probabilistic neural networks [7000-55]

Y. Sheng, K. Zhang, C. Ye, C. Liang, J. Li, Nanjing Normal Univ. (China)

$70001 \mathrm{~J}$ Invariant approach to the character classification [7000-57]

K. Šariri, N. Demoli, Institute of Physics (Croatia)

$70001 \mathrm{~K} \quad$ Fast deconvolution with non-invariant PSF for 3-D fluorescence microscopy [7000-58]

E. Maalouf, B. Colicchio, A. Dieterlen, Univ. de Haute Alsace (France)

$70001 \mathrm{M} \quad$ Gray level image reconstruction using Jacobi-Fourier moments [7000-60]

A. Padilla-Vivanco, Univ. Politécnica de Tulancingo (Mexico); C. Toxqui-Quitl, Univ. Politécnica de Tulancingo (Mexico) and Instituto Nacional de Astrofísica, Óptica y Electrónica (Mexico); C. Santiago-Tepantlan, Univ. Politécnica de Tulancingo (Mexico)

$70001 \mathrm{~N} \quad$ High-speed smart camera with embedded feature extractions and profilometry measurements [7000-61]

J. Dubois, Lab. Le2i, Univ. de Bourgogne, CNRS (France); R. Mosqueron, Ecole Polytechnique Fédérale de Lausanne (Switzerland); M. Paindavoine, F. Beguin, C. Clerc, K. Khattab, Lab. Le2i, Univ. de Bourgogne, CNRS (France)

700010 Improvement of recording density by using a Wiener filter in multiplexed hologram recording [7000-62]

S. Yoshida, M. Saitoh, Y. Ohuchi, M. Tanaka, M. Yamamoto, Tokyo Univ. of Science (Japan)

$70001 Q \quad$ Wavefront coding using coma aberration for dual field of view IR systems [7000-64] J. M. Infante, M. C. de la Fuente, Indra Sistemas SA (Spain)

$70001 \mathrm{~S} \quad$ Shape measurement of transparent objects with polarization imaging [7000-65] M. Ferraton, C. Stolz, F. Mériaudeau, Lab. Le2i, Univ. de Bourgogne, CNRS (France) 
7000 IT Study of the holographic phase stitching technique [7000-67]

C. Dai, Y. Yu, G. Chen, Shanghai Univ. (China); A. Asundi, Nanyang Technological Univ. (Singapore)

7000 iU A dynamic three-dimensional display technique based on liquid crystal spatial light modulator [7000-68]

H. Zheng, Y. YU, T. Wang, Shanghai Univ. (China); A. Asundi, Nanyang Technological Univ. (Singapore)

$70001 \mathrm{~V}$ Advances in LCOS SLM characterization for improved optical performance in image processing [7000-69]

J. Otón, M. S. Millán, Technical Univ. of Catalonia (Spain); P. Ambs, Univ. de Haute Alsace, ENSISA, MIPS (France); E. Pérez-Cabré, Technical Univ. of Catalonia (Spain)

7000 IW 3D imaging of radioactivity in man measured with a whole body counter [7000-70] R. Novario, F. Tanzi, Univ. of Insubria (Italy); S. Rodà, Univ. of Milan (Italy); C. Bianchi, G. Quadrelli, L. Conte, Univ. of Insubria (Italy)

7000 IY Partial volume correction of whole body PET images using the wavelet transform [7000-72] A. E. Spinelli, L. Guerrieri, D. D'Ambrosio, R. Franchi, S. Boschi, M. Marengo, Policlinico Universitario S. Orsola-Malpighi (Italy)

700012 Determining locus and periphery of optic disk in retinal images [7000-73] M. Norouzi Fard, A. Salehi, Islamic Azad Univ. (Iran); J. Shanbeh Zadeh, Tarbiat Moallem Univ. (Iran)

700020 Algorithms improvement in image processing for optical observations of artificial objects in geostationary orbit with the TAROT telescopes [7000-74]

M. Bourez-Laas, Observatoire de Haute Provence, CNRS (France); A. Klotz, Observatoire de Haute Provence, CNRS (France) and Ctr. d'Etude Spatiale des Rayonnements, CNRS (France); G. Blanchet, Ctr. National d'Etudes Spatiales (France); M. Boër, Observatoire de Haute Provence, CNRS (France); E. Ducrotté, Ctr. National d'Etudes Spatiales (France)

$700021 \quad$ Feature-constrained surface reconstruction approach for point cloud data acquired with 3D laser scanner [7000-75]

Y. Wang, Y. Sheng, G. Lu, P. Tian, K. Zhang, Nanjing Normal Univ. (China)

700022 Atmospheric correction for inland water based on Gordon model [7000-76] Y. Li, H. Wang, J. Huang, Nanjing Normal Univ. (China)

700023 Mapping of alpine grassland cover in western China from normalized Landsat TM image [7000-77]

Y. Zha, Nanjing Normal Univ. (China); J. Gao, Univ. of Auckland (New Zealand)

700024 Example based learning of image stitching for an omni-directional camera using a variational optical flow methodology [7000-78]

T. Nir, N. Karpel, RAFAEL Advanced Defense Systems (Israel)

700025 Quantitative retrieval of chlorophyll-a by remote sensing based on TM data in Lake Taihu [7000-79]

H. LU, J. Huang, Y. Li, Nanjing Normal Univ. (China) 
700026 Retrieval of land cover information under thin fog in Landsat TM image [7000-80]

Y. Wei, Nanjing Normal Univ. (China)

700027 Landsat TM image feature extraction and analysis of algal bloom in Taihu Lake [7000-81] Y. Wei, W. Chen, Nanjing Normal Univ. (China)

700028 A novel multi-focus image fusion algorithm based on feature extraction and wavelets [7000-83]

R. Nava, B. Escalante-Ramírez, Univ. Nacional Autónoma de México (Mexico); G. Cristóbal, CSIC (Spain)

700029 SONAR images despeckling using a Bayesian approach in the wavelet domain [7000-84] S. Moga, GET / ENST Bretagne, CNRS (France); A. Isar, Politehnica Univ. Timisoara (Romania)

7000 2A Multi-sensor image fusion with the steered Hermite transform [7000-85]

B. Escalante-Ramírez, Univ. Nacional Autónoma de México (Mexico); A. A. López-Caloca, Ctr. de Investigación en Geografía y Geomática (Mexico)

$70002 B \quad$ The location-searching of image-carrying fiber bundles based on Kalman filter [7000-86] B. An, Shanghai Maritime Univ. (China), Shanghai Institute of Technical Physics (China), and Central Research Academy of SVA Group Co., Ltd (China); J. Gao, Shanghai Maritime Univ. (China); G. Wang, Central Research Academy of SVA Group Co., Ltd (China)

7000 2E Digital holographic microscope with low spatial and temporal coherence of illumination [7000-89]

H. Janečková, P. Kolman, Brno Univ. of Technology (Czech Republic); P. Veselý, Institute of Molecular Genetics AS CR (Czech Republic); R. Chmelík, Brno Univ. of Technology (Czech Republic)

Author Index 
Downloaded From: https://www.spiedigitallibrary.org/conference-proceedings-of-spie on 26 Apr 2023

Terms of Use: https://www.spiedigitallibrary.org/terms-of-use 


\title{
Conference Committee
}

\author{
Symposium Chairs
}

Hugo Thienpont, Vrije Universiteit Brussel (Belgium)

Patrick P. Meyrueis, Université Louis Pasteur (France)

Giancarlo C. Righini, Istituto di Fisica Applicata Nello Carrara, CNR (Italy)

Conference Chairs

Peter Schelkens, Vrije Universiteit Brussel (Belgium)

Touradj Ebrahimi, École Polytechnique Fédérale de Lausanne

(Switzerland)

Gabriel Cristóbal, Consejo Superior de Investigaciones Científicas

(Spain)

Frédéric Truchetet, Université de Bourgogne (France)

Program Committee

Boris Escalante-Ramírez, Universidad Nacional Autónoma de México (Mexico)

Walter J. Husak, Dolby Laboratory Inc. (USA)

Bahram Javidi, University of Connecticut (USA)

Pascuala García-Martínez, Universidad de València (Spain)

Maria S. Millán García-Varela, Universidad Politècnica de Catalunya (Spain)

Didier Nicholson, Thales Group (France)

Colin J. R. Sheppard, National University of Singapore (Singapore)

Athanasios N. Skodras, University of Patras (Greece)

Andrew G. Tescher, AGT Associates (USA)

\section{Session Chairs}

1 Holography-Interferometry

Pascuala García-Martínez, Universidad de València (Spain)

Gabriel Cristóbal, Consejo Superior de Investigaciones Científicas

(Spain)

Javier Garcia Monreal, Universidad de València (Spain)

2 Industrial Applications

Maria S. Millan Garcia-Varela, Universidad Politècnica de Catalunya (Spain) 
3 Wavelet Methods

Frédéric Truchetet, Université de Bourgogne (France)

4 Compression Technologies

Peter Schelkens, Vrije Universiteit Brussel (Belgium)

$5 \quad$ Advanced Camera Systems

Touradj Ebrahimi, École Polytechnique Fédérale de Lausanne

(Switzerland)

Athanasios N. Skodras, University of Patras (Greece)

$6 \quad$ Wavelet Applications and Denoising

Frédéric Truchetet, Université de Bourgogne (France)

$7 \quad$ Watermarking

Boris Escalante-Ramirez, University Nacional Autónoma de México (Mexico)

$8 \quad$ Advanced Imaging

Boris Escalante-Ramirez, Universidad Nacional Autónoma de México (Mexico)

$9 \quad$ Medical Imaging

Gabriel Cristóbal, Consejo Superior de Investigaciones Científicas

(Spain)

10 Interaction between Optics and Digital Image Processing Pascuala García-Martínez, Universidad de València (Spain)

Maria S. Millan Garcia-Varela, Universidad Politècnica de Catalunya (Spain) 


\title{
Introduction
}

In recent years, Moore's law has fostered the steady growth in the field of digital image processing, though computational complexity remains a significant problem for most of the digital image processing applications. At the same time, research in the field of optical image processing has matured, potentially bypassing the limitations of digital approaches and giving rise to new applications. The aim of this conference was to create a joint forum for both research and application communities to share expertise, to solve present-day application bottlenecks, and to propose new application areas. Consequently, this conference had a broad scope, ranging from basic and applied research to dissemination of existing knowledge.

This volume consists of the papers presented at the SPIE Optical and Digital Image Processing Conference which took place from 7-9 April, 2008, in Strasbourg, France.

The contributions were grouped in sessions covering holography-interferometry, industrial applications, wavelet methods, compression technologies, advanced camera systems, wavelet applications and denoising, watermarking, advanced imaging medical imaging, and the interaction between optics and digital image processing. We thank all the participants and all those who worked hard to make this conference so successful. Special thanks to all the reviewers that helped us to improve the quality of the final proceedings.

\author{
Peter Schelkens \\ Touradj Ebrahimi \\ Gabriel Cristóbal \\ Fred Truchetet
}


Downloaded From: https://www.spiedigitallibrary.org/conference-proceedings-of-spie on 26 Apr 2023

Terms of Use: https://www.spiedigitallibrary.org/terms-of-use 